University of Nebraska - Lincoln

DigitalCommons@University of Nebraska - Lincoln

PreColumbian Textile Conference VIII /

Jornadas de Textiles PreColombinos VIII (2019)

Centre for Textile Research

$5-2020$

\title{
A highland textile tradition from the far south of Peru during the period of Inka domination
}

Penelope Dransart

Follow this and additional works at: https://digitalcommons.unl.edu/pctviii

Part of the Art and Materials Conservation Commons, Fiber, Textile, and Weaving Arts Commons, Indigenous Studies Commons, Latin American Languages and Societies Commons, Museum Studies Commons, and the Other History of Art, Architecture, and Archaeology Commons

This Article is brought to you for free and open access by the Centre for Textile Research at DigitalCommons@University of Nebraska - Lincoln. It has been accepted for inclusion in PreColumbian Textile Conference VIII / Jornadas de Textiles PreColombinos VIII (2019) by an authorized administrator of DigitalCommons@University of Nebraska - Lincoln. 


\title{
A highland textile tradition from the far south of Peru during the period of Inka domination
}

\author{
Penelope Dransart \\ University of Aberdeen
}

\begin{abstract}
A group of garments and textile fragments is identified in this article as belonging to a particular textile tradition, with characteristics indicating an affiliation to communities in the highlands of the South-Central Andes. Different categories of gender-specific garments are presented. The characteristics include an all-camelid construction, warp-patterned stripes in blocks of alternating colours, the use of a discontinuous warp and transposed-warp weave. Pattern motifs include eightpointed stars, double-headed serpents and figures based on rhombuses. Distinctive geometric designs are analysed, including 'butterfly' motifs and narrow stripes, consisting of paired light- and dark-coloured right-angled triangles joined to make stacks of larger isosceles triangles or rhombuses. These are compared with pottery styles of the Collao, the region surrounding Lake Titicaca, and of the Inkas, who conquered the region c. 1440. Some textiles are reported in museum catalogues to have been found on sites in the Yauca, Majes and Sihuas valleys. It is hypothesized that the textiles preserved in museum collections are from funerary sites in southern Peru from the 1470 s onwards when Qolla and Lupaqa lordships established enclaves in coastal valleys under the aegis of the Inka empire.
\end{abstract}

Key words: Warp-woven textiles, gendered garments, South-Central Andes, Lake Titicaca kingdoms, Qolla (Colla), Lupaqa (Lupaca), Late Horizon

\section{Resumen}

En este artículo se identifica a un grupo de tejidos que corresponden a una específica tradición textil con características que pertenecen a las tierras altas del área Centro Sur Andina. Se presentan diferentes categorías de prendas según el género del usuario. Los textiles están tejidos con urdimbre y trama de fibra de camélido en listas ejecutadas en faz de urdimbre con dibujos en bloques de colores alternos, con el uso de hilos de urdimbre discontinuos y de hilos de urdimbre transpuestos. Los motivos incluyen estrellas de ocho puntas, serpientes de dos cabezas y figuras basadas en rombos. Se analizan los motivos geométricos distintivos de 'mariposa' y listas angostas, compuestas de triángulos ortogonales de colores oscuros y claros que se juntan para formar triángulos isosceles y rombos. Luego se comparan los motivos con los diseños de la cerámica del Collao, la región que rodea el Lago Titicaca, y de los Inkas, que conquistaron la región c. 1440. Según lo registrado en los catálogos de museo, algunos de los textiles se han encontrado en los valles de Yauca, Majes y Sihuas. Se presenta una hipótesis de que los textiles conservados en colecciones de museo provenían de sitios funerarios en el sur de Perú desde la década de 1470 en adelante, cuando los señoríos Qolla y Lupaqa establecieron enclaves en los valles costeros bajo los auspicios del imperio inca.

Palabras clave: Textiles faz de urdimbre, prendas masculinas y femeninas, área Centro Sur Andina, señoríos del Lago Titicaca, Qolla (Colla), Lupaqa (Lupaca), Horizonte Tardío

\section{Résumé}

Dans cet article est examiné un groupe de vêtements et de fragments de tissus appartenant à une même tradition textile et présentant des caractéristiques propres aux communautés des hautes terres de la région andine centre-sud. On y trouve différentes catégories de vêtements portés selon le genre. Les tissus sont tissés entièrement en fibres de camélidés et à dominante chaîne, avec des motifs organisés en blocs de couleurs alternées, des fils de chaîne discontinus et d'autres transposés.

DOI: 10.32873/unl.dc.zea.1209

Published in PreColumbian Textile Conference VIII / Jornadas de Textiles PreColombinos VIII, ed. Lena Bjerregaard and Ann Peters (Lincoln, NE: Zea Books, 2020). https://digitalcommons.unl.edu/zeabook/ 
Les motifs incluent des étoiles à huit pointes, des serpents à deux têtes, et des figures en forme de losanges. Des motifs géométriques sont analysés, en particulier des motifs de " papillons », et des rayures étroites composées de triangles orthogonaux de couleurs foncées et claires qui se joignent pour former des triangles isocèles de plus grande taille et des losanges. Ceux-ci sont ensuite comparés aux motifs présents sur la céramique du Collao, région autour du lac Titicaca, et sur la céramique des Incas qui conquirent la région autour de 1440. Selon les registres des catalogues des musées, certains textiles ont été découverts dans les vallées de Yauca, Majes et de Sihuas. Nous présentons l'hypothèse que les tissus conservés dans les collections muséales proviennent de sépultures du sud du Pérou, datant des années 1470 et au-delà, lorsque les señoríos Qolla et Lupaqa ont installé des enclaves dans les vallées côtières sous l'égide de l'empire Inca.

Mots clés: tissus à dominante chaîne, vêtements masculins et féminins, région andine centre-sud, señoríos du lac Titicaca, Qolla (Colla), Lupaqa (Lupaca), Horizon Récent

In the sixteenth century, Pedro de Cieza de León commented on the region surrounding Lake Titicaca, which he called Collao or Collas. Not only was it extensive in size, but the density of its population, he said, was greater than he had seen elsewhere in the Andes (Cieza de León 2005[1553]: 253). In describing its people, he commented 'Andan vestidos de ropa de lana ellos y sus mugeres', with the men also wearing long bonnets called chuco and the women a hood, which was nearly as long as those worn by mendicant friars (Cieza de León 2005[1553]: 255). ${ }^{1}$ South of the Collao region, he observed that 'andan vestidos los naturales de la provincia de Paria como todos los demás, y traen por ornamentos en las cabezas un tocado a manera de bonetes pequeños hechos de lana' (Cieza de León 2005[1553]: 267). ${ }^{2}$ As he travelled through the Andes, the people's headdress, in particular, attracted his attention and he referred to it as signalling the wearer's ethnic affiliation and gender identity. In contrast, he did not see the garments of the inhabitants of Paria as being particularly distinctive compared with those of other peoples in the Andean highlands.

This lack of ethnic distinctiveness, apart from the headgear, provides a significant starting point in an examination of people's dress from the highlands of the far south of Peru (Figure 1). In this article, I present descriptions of men's and women's garment types as well as of fragments of garments that have been considered to be 'provincial Inka' in style (Rowe 1992), dating from the period when highland communities established enclaves in coastal valleys. These textiles have a camelid fibre warp and weft, are woven in warp-faced or warp predominant techniques, and they make use of a particular iconographic repertoire that can also be detected in certain ceramic designs belonging to the Collao and to the Late Horizon, a period during which the highlands of the far south of Peru came under Inka control.
The textile tradition identified in this article was perhaps shared by different highland communities east of the western Cordillera de los Andes in the Department of Puno, including Qolla and Lupaqa peoples, who were named in documentary sources during the Colonial Period, and by inhabitants of the sierra in the Department of Arequipa west of the Cordillera. My interpretation of the available evidence suggests that this textile tradition was not the exclusive preserve of one discrete population. A warning is in order, lest readers of this article be tempted to make a one-to-one correspondence between the textiles and a historically named community of people. The difficulty Cieza de León had in distinguishing between the main garments worn by people is reinforced by the evidence I present here, based on the study of dress types, iconographic motifs and associated ceramic designs.

In what follows, I briefly review literature published on other textile traditions in the far south of Peru and far north of Chile, to provide a background for this newly identified textile tradition. Details are provided of some of the known places where the textiles have been found. Men's tunics are described, then women's dresses, plus other items, including bags. There follows a discussion of documentary and archaeological evidence, which provides contextual assistance to suggest where the textiles might have been woven. A concluding discussion considers how items of dress were gendered, using entries in the dictionary compiled by the Italian Jesuit Ludovico Bertonio (1612). Like Cieza de León, he found people's expressed their ethnicity in headgear, rather than in their main garments. His dictionary entries, however, provide extremely useful information on gender distinctions, helping to demonstrate how the textiles were worn.

1. 'They [the men] and their women go around dressed in wool'. All translations are mine unless otherwise stated. The 'wool' to which Cieza referred is likely to have been camelid fibre.

2. 'The natives of the province of Paria go around like all the rest, and wear for ornaments on their heads a headdress in the manner of small cap made from wool'. 


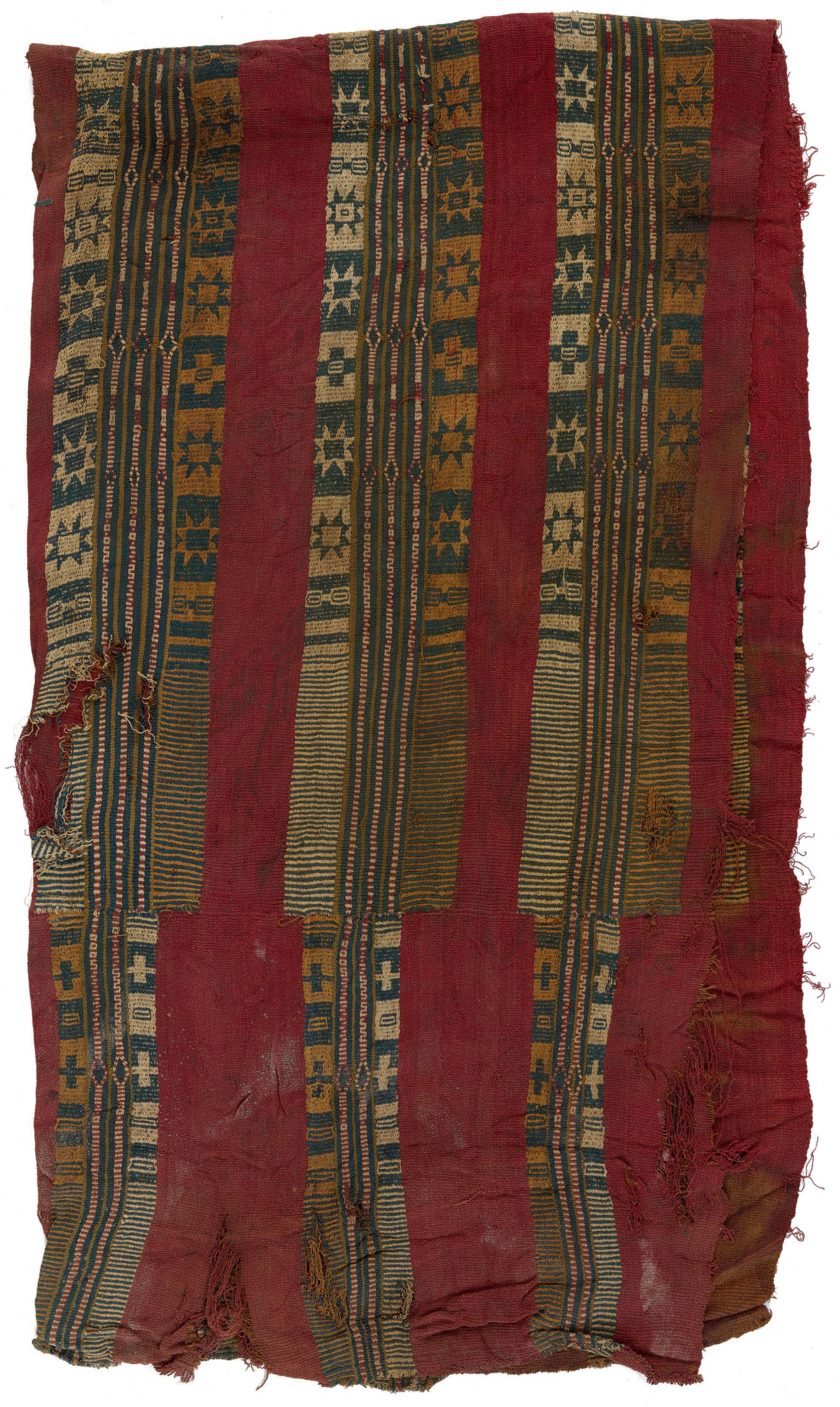

Figure 1. Half of a tunic from the highlands, far south of Peru, woven in warp-faced plain weave, complementary-warp weave pattern stripes (with an uneven warp count), transposed-warp rhombuses in narrow red and white stripes, and a discontinuous warp. A surviving portion of the seam is visible at the upper right of this view.Textile Museum, Washington DC TM1961.30.210, Burton I. Jones. 


\section{Textile traditions in the far south of Peru and far north of Chile}

Arid environmental conditions in coastal valleys favour the preservation of textiles whereas the finds of textiles on highland sites are extremely rare. Scholars have, in particular, made considerable advances in identifying the textile traditions of coastal peoples in the far south of Peru and the far north of Chile, especially after the disintegration of the Wari and Tiwanaku empires from about AD goo to 1000. In Peru, a tradition known as Ilo-Tumilaca became focused in the western valleys of the piedmont, with an equivalent called Cabuza in the far north of Chile (Boytner 1998). During the period between c.90o to c.1350, a different tradition called Chiribaya emerged and became strongly associated with people settled in coastal locations (Umire and Miranda 2001: 58-59; Minkes 2005). Chiribaya people were culturally related to other groups known as Maytas in the Azapa Valley, in the far north of Chile (Horta 1997: 81; Minkes 2005: 248). These textile traditions have analogous pottery styles. Aspects of the Chiribaya tradition were inherited in the San Miguel, Pocoma and Gentilar phases of a ceramic tradition lasting from c.1250 until c.1550. Its distribution was coastal, south of the Tambo Valley in Peru and northern Chile (Uribe Rodríguez 1999: 207-218; Covey 2000: 125). In the Lluta and Azapa Valleys these ceramic phases are associated with changing textile styles which, together, constitute what is known as the Arica culture (Ulloa 1982a, 1982b; Horta 2005).

Mary Frame's comprehensive study of male and female garment types belonging to a highland tradition known as Chuquibamba, dated between 1000 and 1475, provides another milestone in textile research from the south of Peru (Frame 1997-98; Tessier-Brusetti 2016). Chuquibamba ceramics occur with motifs painted in polychrome as well as black on red variants, having been identified in the 1940 s by Alfred L. Kroeber (1944: 19-22, 145-146). Linear pottery designs in black on red have a parallel in the black outlining that also occurs in some Chuquibamba textiles (Frame 1997-98: 4). The textiles were woven on a wide upright loom using camelid fibre warp and weft, the patterning executed in weft-faced techniques (Figure 2). While Chuquibamba itself is in the Río Ocoña drainage, other examples have been found in coastal locations where the Majes-Camaná and Sihuas-Quilca Rivers drain into the Pacific. The northernmost finds of Chuquibamba textiles are reported from cemeteries in the Nasca Valley and Ica, with the distribution reaching as far south as Mollendo.

The main garment of women and men in coastal and piedmont valley communities was a camisa or tunic that was seamed under the arms (Minkes 2005: 218-221). In the sierra of Arequipa and in Titicaca lakeside communities, women wore an untailored dress wrapped round the body, while their male counterparts wore tunics. This also was the practice of Chuquibamba women and men (Frame 1997-98) (see, again, Figure 2).

Although eight-pointed star motifs figure prominently in both Chuquibamba and the newly identified tradition, the styles are distinct. Many of the other motifs are unalike. In Chuquibamba textiles, motifs frequently appear in tabbed rectangles repeated in diagonal alignment (Figure 2), a patterning analysed by Frame (1997-98). This form of spatial organization is strikingly different from the vertical stacking of patterns in Titicaca textiles. There are also marked differences in the colour palettes used, because clear light green, yellow and bright red are characteristic of Chuquibamba textiles, while dark red, dark blue and yellow ochre combined with white appear in the warp-faced textiles (Rowe 1992: 33).

The eight-pointed star is a motif with ancient antecedents, but the form in which it occurs in late pre-Hispanic times acquired a particular currency during the period of Inka dominance in the second part of the fifteenth century (Rowe 1992: 31-33). Volutes in the shape of an 'S' or a reversed ' $S$ ' and rhombuses with four hooks also had a long currency going back at least to Tiwanaku or Nasca times. Motifs used characteristically in the belts, bags and carrying cloths of Chiribaya and Maytas textiles survived the decline of these traditions after c.1350. During the Late Horizon, weavers in both the highlands and coastal valleys adapted them for use in tunics, loincloths, dresses and other items. In addition to eight-pointed stars and rhombuses with four hooks, other motifs that spread widely include stylized serpents with a head at each end, 'frogs' with three digits, and a hexagonal 'eye' motif (Frame 1997-98: 13, figure 19c; Horta 1997: figures 4 and 36; Dransart 2000: 149, 153; Umire and Miranda 2001: figures 33 and 34; Minkes 2005: 142 and 249).

Recycled ancient motifs can make some of these textile traditions look superficially similar. Luis Lumbreras (1974: 197) included an image of a textile from the tradition defined in this article alongside two Chuquibamba textiles, labelling all three as Ica-Chincha in style. Despite Ann Rowe's (1992: 33) pertinent questions intended to help disentangle the relationships between the traditions, and Frame's (1997-98) precise definition of Chuquibamba textiles, some authors have categorized Late Horizon warp-faced textiles as Chuquibamba (Arnold and Espejo 2012: 203, 2015: 256), Chiribaya (Rosenzweig and Artzi 2011: 100, figure 9) or hybrid Chiribaya-Chuquibamba (Tessier-Brusetti 2016: 97, figure 2). María Jesús Jímenez Díaz (2004: 396-397) recognized that the warpfaced textiles discussed here belong to an Inka Provincial 


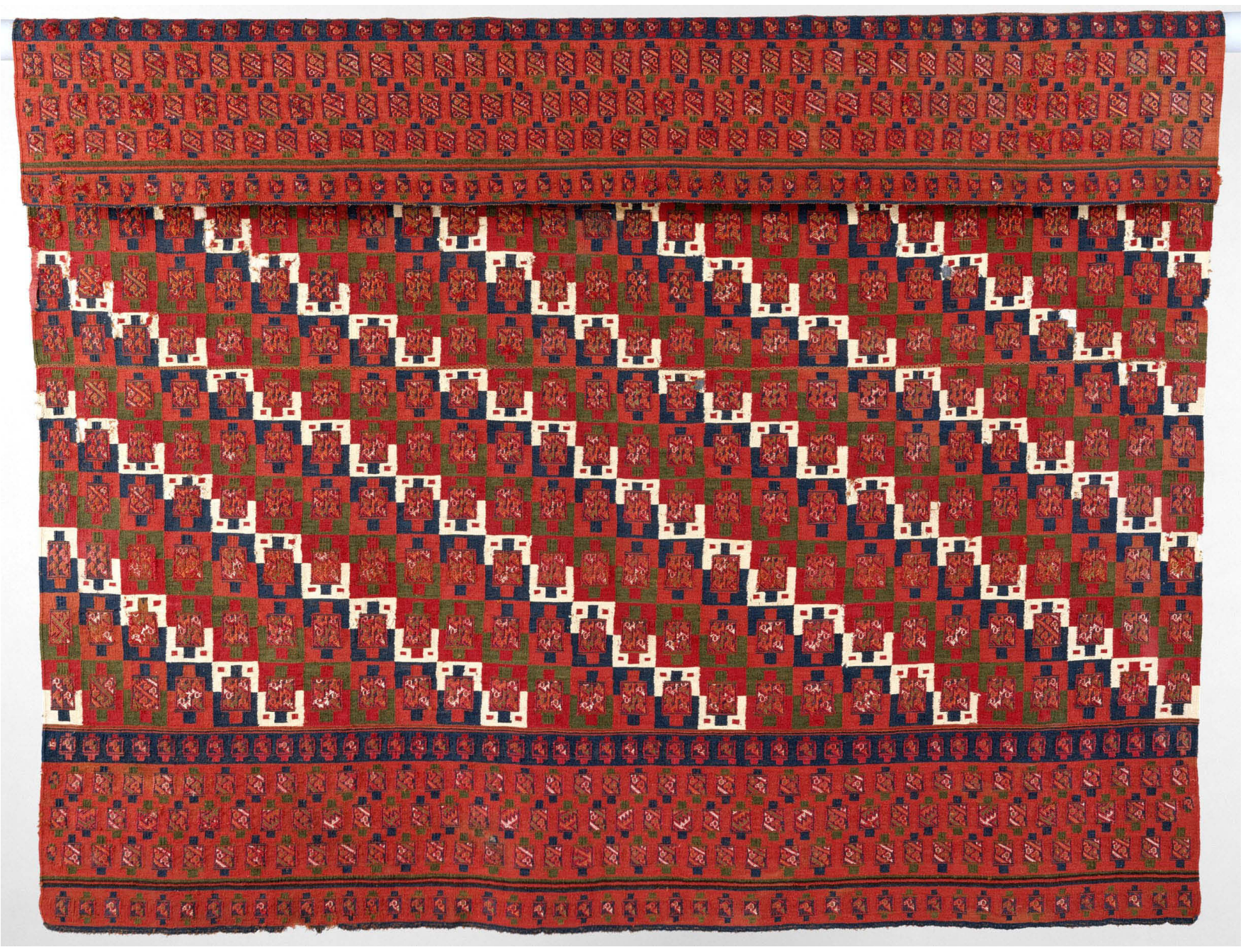

Figure 2. Chuquibamba style woman's dress, woven in weft-faced weaves. Metropolitan Museum of Art. Purchase, Pfeiffer Fund and Arthur M. Bullowa Bequest, 1995 .

category but regarded them as being possibly hybrid 'Chuquibamba-Inka. 3

The catalogue of the Museo Nacional de Arqueología, Arte e Historia del Perú provides an alternative attribution, assigning textiles of the type considered here to the Complejo Arqueológico de Churajón in the Chili Valley, in the Department of Arequipa. ${ }^{4}$ Churajón pottery includes polychrome wares with motifs cursorily painted in black and white on red. Other than an example of a six-pointed star with an elliptical centre (Szykulski 2010: Fig. 108H), there are few correspondences in the published literature between the motifs painted on pottery and those woven in textile. Because
Churajón polychrome wares are painted in similar colours to ceramics from Allita Amaya in Lupaqa territory (Tschopik 1946: 34), and from Mollo, in Bolivia, it might seem that stylistic analogies existed between them. Józef Szykulski (2010: 277, 298-300), however, argues that these apparent correspondences resulted from the independent development of these pottery styles after the collapse of the Tiwanaku state. As will be demonstrated below, there is a specific point of reference between Allita Amaya pottery and the textiles. The designs on Churajón pottery therefore do not provide a basis for lending their name to these textiles with their considerably more precise designs. This lack of

3. At the time of writing this article (2019), misattribution of warp-patterned textiles to the weft-patterned Chuquibamba tradition also occurs in some online museum catalogues. Such textiles include Am1954,05.450 and Am1971,02.8 in the British Museum; o0o0238629 in the Museo Nacional de Arqueología, Arte e Historia del Perú; and 2000.3.124.a, 2000.3.124.b, 2000.3.124.c and 2007.1.14 in Bryn Mawr College Art and Artifact Collections.

4. Museo Nacional de Arqueología, Arte e Historia del Perú online catalogue, accession numbers o0o0141843, 0000142724 and 0000252833. 


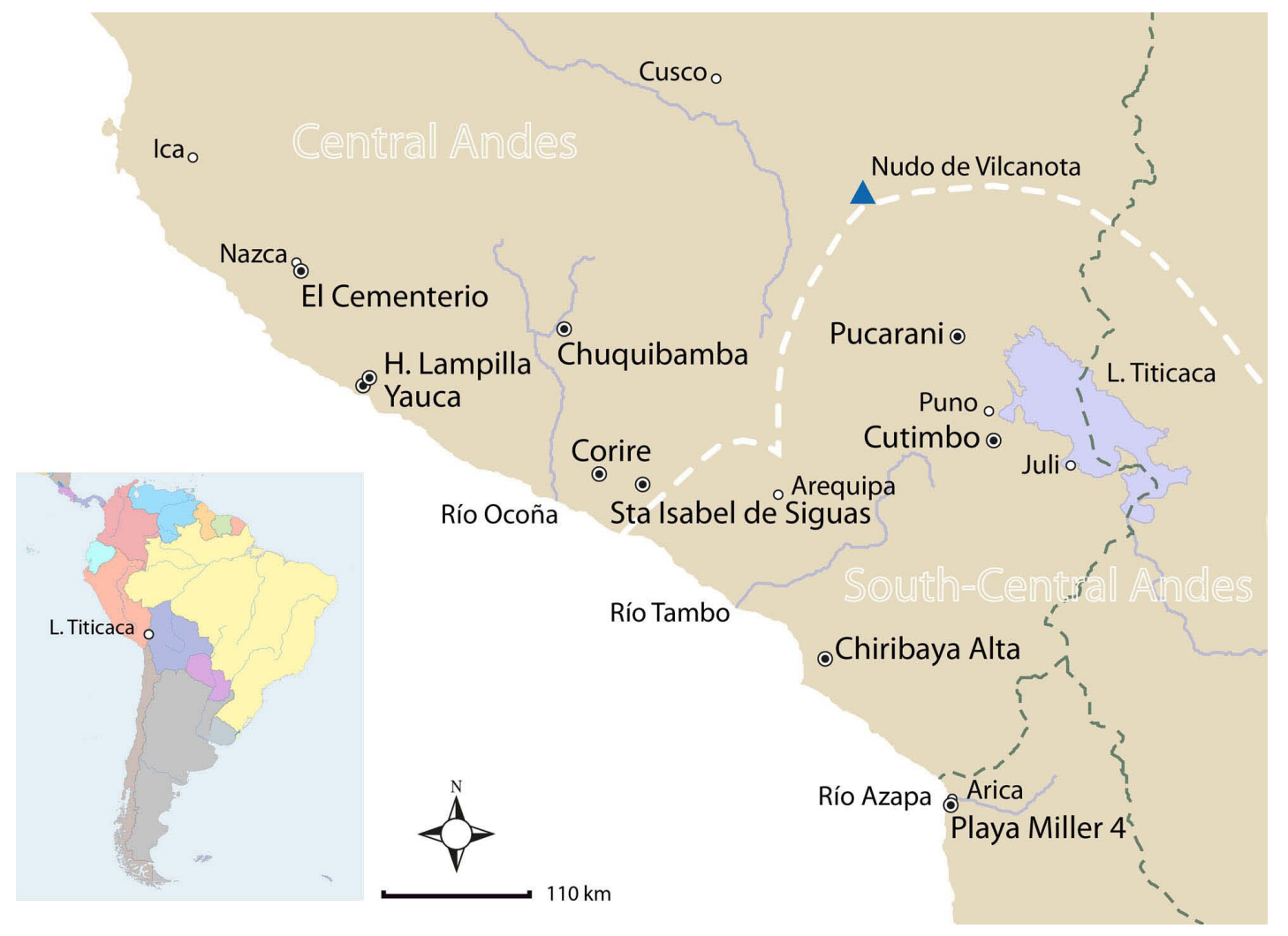

Figure 3. Map of southern Peru showing places mentioned in the text. The white dashed line shows the approximate division between the Central and the South-Central Andes. correspondence, however, does not preclude that the sierra of Arequipa formed part of the broader region in which the textiles were worn. I propose to call these Titicaca Lakeside textiles.

\section{Where textiles in the newly defined tradition have been found}

With few exceptions, most of the textiles studied in museum collections for this article lacked information concerning the location where they were found. Max Uhle recovered three fragments from a man's tunic and women's dresses from tombs on land at the Hacienda Lampilla, situated one mile below Mochica in the Yauca Valley (Figure 3). They are now in the collections of the Phoebe A. Hearst Museum of Anthropology (accession numbers 4-8216, 4-8217 and 4-8218), which has another fragment that Uhle found at Yauca (48164). ${ }^{5}$ The Inkas established an administrative centre at Tambo de Jaqui on what was later to become the Hacienda Lampilla, in an area that had not previously been subject to centralized administration (Menzel 1959: 128). ${ }^{6}$
The excavation of woman's tomb in the San Francisco necropolis near Corire, in the Department of Arequipa, produced a fragment of a woman's dress. Although the burial had been disturbed by grave robbers, archaeologists recovered the fragment, a textile bag and the remains of pottery, including Inka wares (Szykulski and Cárdenas Sumida 1999: 390-392, Figs 7 and 9).

A fringed bag in the collections of the Peabody Museum, Harvard, is reported to have come from the Majes Valley, near Santa Isabel de Siguas (46-81-30/5533). A tunic fragment, also in $\mathrm{PMH}$, is stated to have come from El Cementerio, a site south of the river near Nazca (46-77-30/7386). Another fragment in this museum's collections is said to have come from Huacho on the central coast of Peru (4212-30/3739). This last piece is an outlier in the distribution otherwise occurring between Ica and Mollendo.

One more Titicaca Lakeside tunic fragment occurring in an extraordinary context covers a folder-like container for storing the Exsul Immeritus Blas Valera Populo Suo e Historia, a manuscript dated 1618 , which was written in Latin and Quechua in the hand of Blas Valera (Laurencich Minelli 2000: 155 and 169, figure 1). According to Laura Laurencich

\footnotetext{
5. Henceforth the name of the museum is abbreviated after the first time it is used in this text. For a list of the museums and their abbreviations, as well as the URLs of their online catalogues, please see the list of Museum Collections and Abbreviations below. 6. A tambo, or tampu in Gonçalez Holguin (1608: 337), is glossed in Spanish equivalents as 'venta, o meson' [an 'inn'].
} 
Minelli (2005: 26), the use of the textile and the metaphorical language of the document combine to convey the idea of Inka culture on the periphery of empire that would have nourished its author, Blas Valera, who felt himself to be 'Indian' in colonial society.

\section{Forms of garments and accessories:}

\section{Men's Tunics:}

Of the textiles included in this study, men's tunics and bags are more likely to survive to a degree of completeness compared with other garments, such as women's dresses. Loin cloths have yet to be recognized in museum collections. Complete examples of tunics include one in the Textile Museum, George Washington University (Rowe 1992: figure 36), another in the MNAAHP (inventory no oooo141843), and a third in the Museo de América, Madrid (inventory no 14676; Jiménez Díaz 2004: 396-397). Two further examples, from the Ohara Gallery of Art, have been published in Misugi (1985: 90-91, Plates 155 and 157). Fragments are more frequently preserved (Figures 1, 4, 5 and 7).

Tunics were assembled from two or more panels, woven in warp-faced techniques and stitched together to make a garment broader than tall. The warp was oriented vertically in the garment as worn. Characteristically, the panels are subdivided through the use of a discontinuous warp dovetailed round a horizontal thread (Rowe 1977: 103). The garment is articulated internally in segments but, because the division between segments is not always marked by changing the colour of the warp threads, from a distance the articulation might barely be noticed (Dransart 2014: 226-227). The segments mark the shoulder line of the tunic or form a lower panel. The pattern stripes in the lower panel are usually narrower than in the upper, making the disjunction between the two segments more obvious.

A characteristic feature of the Titicaca Lakeside tunics is that the pattern stripes begin and end in horizontal bars, formed by alternating two different colours of warp threads in plain weave. This design is termed peinecillo in Spanish and k'uthu in Aymara (Espejo and Arnold 2014: 305-308). In contemporary Aymara textiles, which are woven with four selvedges, a short area of $k$ 'uthu often marks where the warp threads have become too short for the weaver to lift to form the pattern and she enters the final weft threads using a needle. The weavers of these textiles instead made extensive use of k'uthu to form part of the design. In tunics, $k$ 'uthu occurs at the lower edges of the upper and lower segments of panels separated through the use of a discontinuous warp (Figure 5).
The pattern stripes are grouped. Broader stripes containing decorative motifs stacked one above the other are separated by two or three narrow stripes executed in red and white $k$ 'uthu and embellished with other patterns. At intervals, the warp threads are transposed to form a rhombus shape (Rowe 1977: 104). Half of the threads in the narrow stripe take a diagonal trajectory to the left and the other half to the right, with both sides coming back together to complete the rhombus shape. This very distinctive form of patterning is characteristic of textiles produced across the highlands and coast of the far south of Peru, northern Chile and north-west Argentina (Rowe 1977: 104; Dransart in press). Figure 1 presents an example of how it was used in tunics of the newly identified tradition and Figure 6 in a carrying cloth from a coastal site south of the Azapa Valley, Chile, during the Period of Regional Developments, c.110o to c.1476 (also known as the Late Intermediate Period).

The broad pattern stripes are executed in a complementary-warp weave, alternating between light on dark and dark on light, using a technique of selecting warp threads based on an odd count (Arnold and Espejo 2015). Usually a vertical colour change divides the stripe; frequently dark blue alternates with tan or yellow ochre on one side of the stripe and dark blue alternates with white on the other (Figures 1, $4,5,7)$. Exceptions include one of the complete tunics in the OGA (Misugi 1985: 90, no 155), a fragment in the MNAAHP (T-19744 in Dransart 2014: 227), as well as the panel in Figure 7. These three examples lack a vertical colour division.

Eight pointed stars and cruciform shapes are the most commonly encountered design motifs in tunics. Ann P. Rowe (1992: 31) described the visual appearance of the star as a 'square with two right triangles projecting off each of the four sides' and commented that the term is purely conventional since it is not known what the motif was called in the past. Because Titicaca Lakeside textiles have sometimes been assigned to Chuquibamba, it is important to note that the centre of the star is of the same colour as the background, whereas in Chuquibamba textiles it is different. A different coloured centre in an eight-pointed star also occurs on Chuquibamba ceramics. This feature might have been inspired by the weave because tapestry gave the weaver more freedom to change the weft yarn than weaving the pattern in the warp using complementary pairs of yarns in two colours.

To term the cruciform shape a 'cross' is equally conventional (Figures 1 and 4). Similar motifs are known in textiles and stone carving from the pre-Tiwanaku culture of Pukara (c.400 BC - c.AD 350) (Cuynet 2010: 222, Fig. 6).

Another motif, which sometimes occurs in pattern stripes, appears to have a figurative referent because it is based on a rhombus with 'limbs' projecting at four corners, 


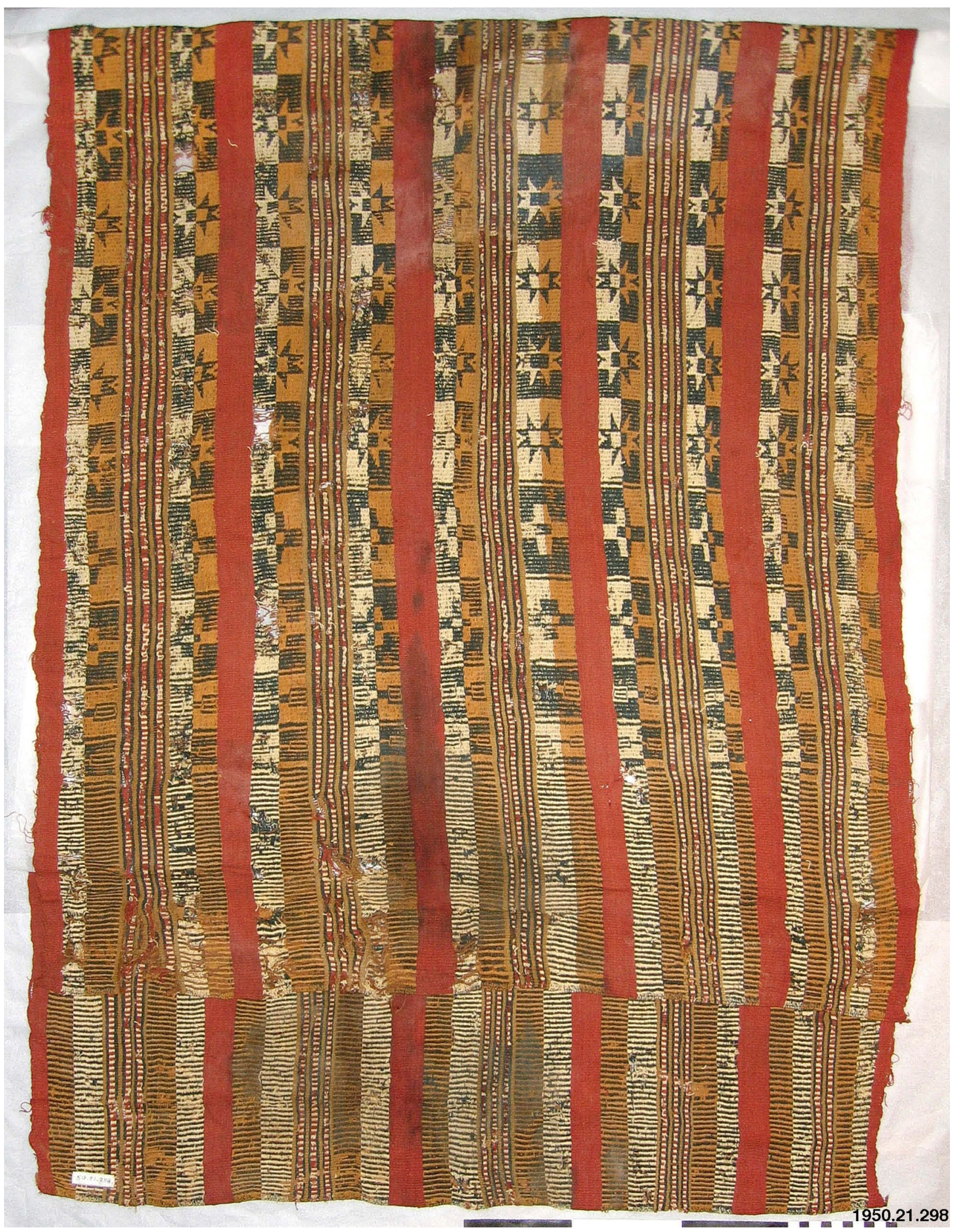

Figure 4. Tunic panel from the highlands, far south of Peru, woven in warp-faced plain weave and complementary-warp weave (with an uneven warp count). There are long areas of $k^{\prime} u t h u$ or peinecillo bars at each end of the panel. Varldskultur Museerna: Etnografiska, Stockholm, 1950.21.298 


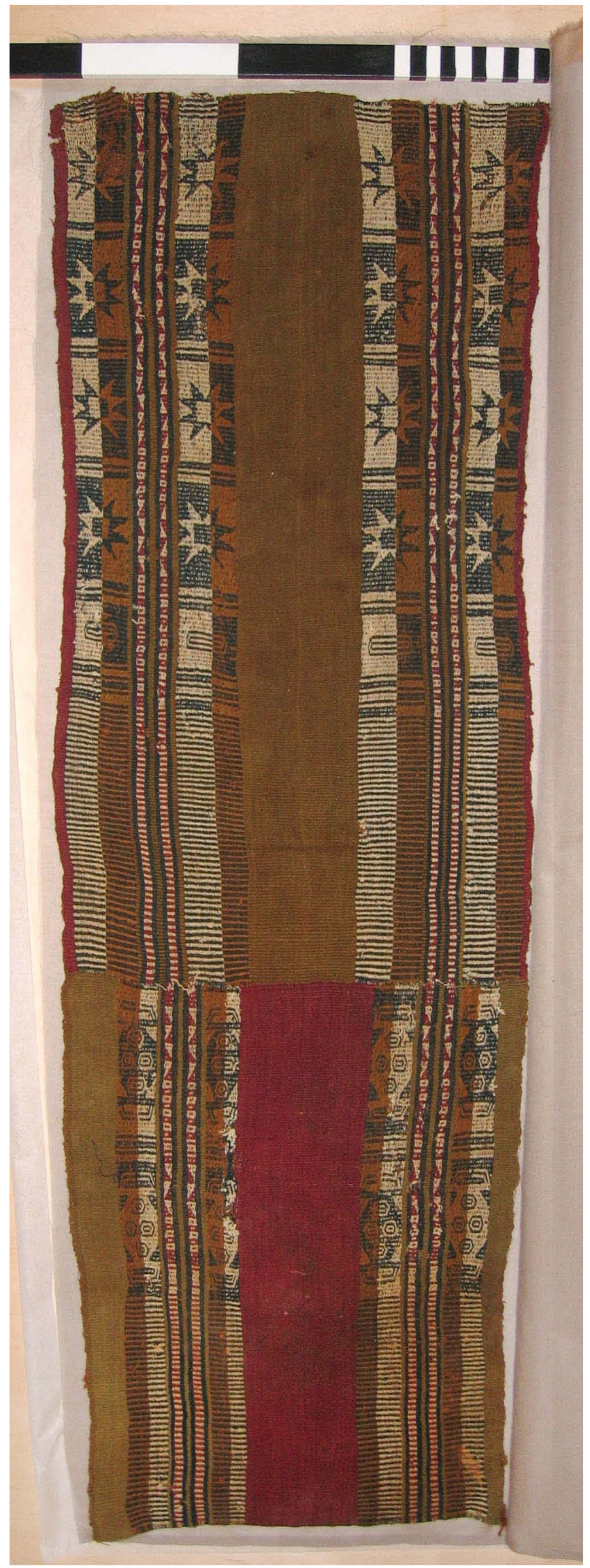

Figure 5. Fragmentary panel from the highlands, far south of Peru, woven in warp-faced plain weave, complementary-warp weave (with an uneven warp count) and a discontinuous warp. Varldskultur Museerna: Etnografiska, Stockholm, 1951.24.0025

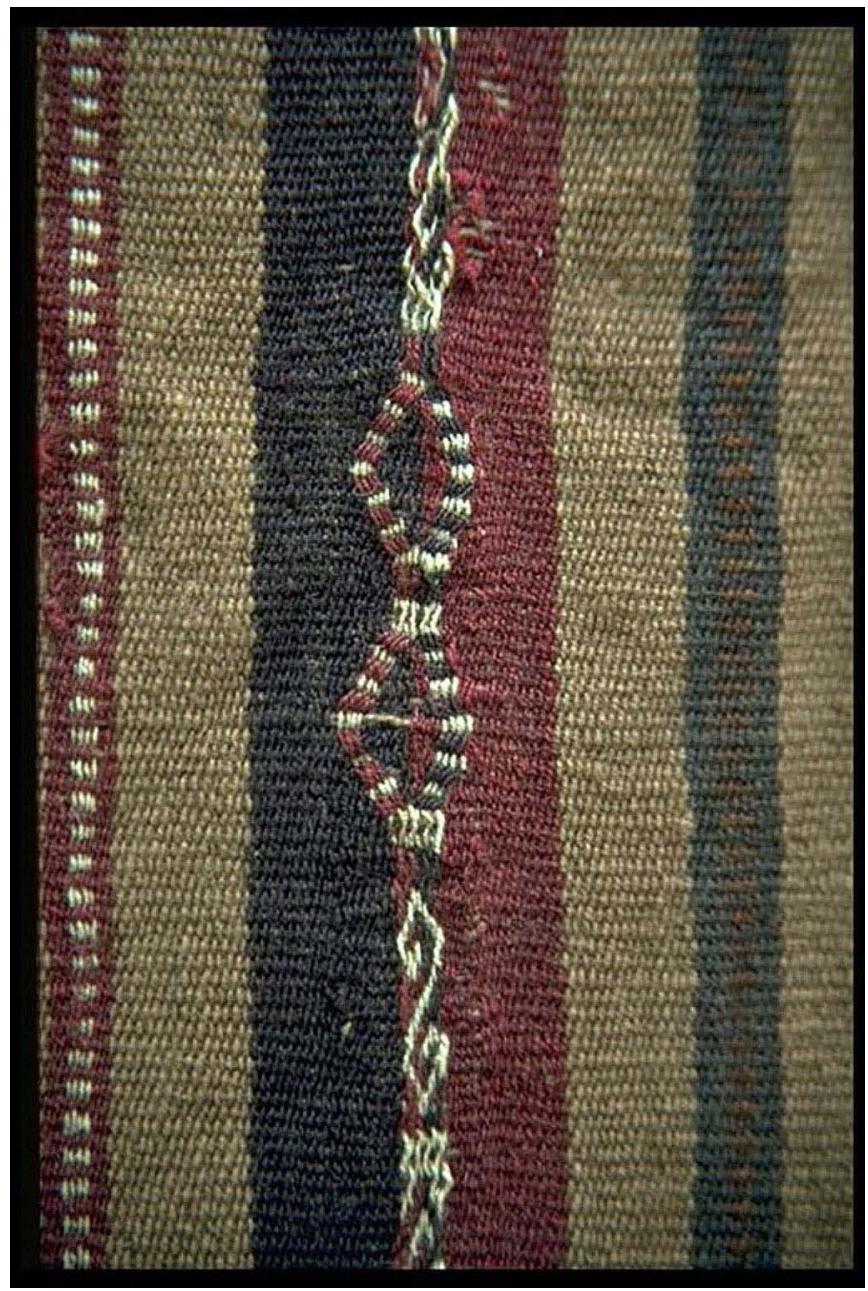

Figure 6. Detail of a carrying cloth belonging to the Arica culture, No 7003 from tomb 27, site Playa Miller 4 at the mouth of the Azapa Valley, northern Chile. This detail shows warp-faced plain weave stripes (including narrow stripes of $k^{\prime} u t h u$ ) and transposed warp rhombuses. Photograph: Penelope Dransart, by courtesy of the Museo Universidad de Tarapaca San Miguel de Azapa. 


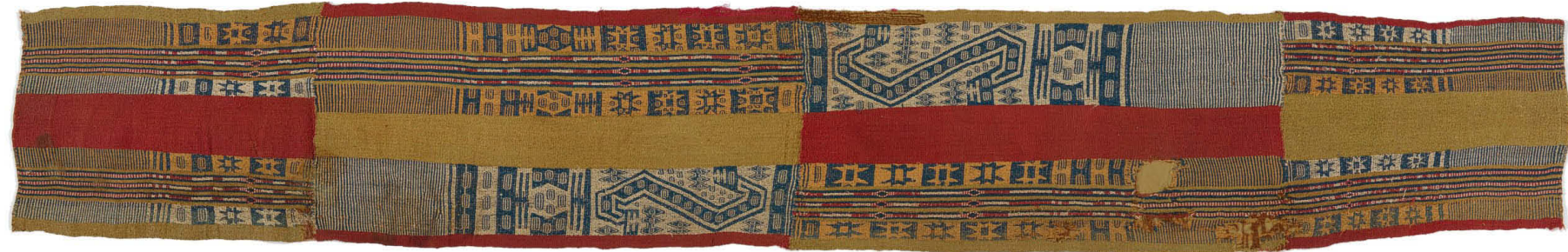

Figure 7. Tunic panel from the highlands, far south of Peru. It is woven in warp-faced plain weave, complementary-warp weave (with an uneven warp count), transposed-warp rhombuses in narrow red and white stripes, and a discontinuous warp. Textile Museum, George Washington University TM91.46o, acquired by George Hewitt Myers in 1950.

each limb having two or three 'digits' (Figure 7). It is, perhaps, a more stylised version of zoomorphic spiders or lizards that featured in the earlier Chiribaya and San Miguel textile traditions (Minkes 2005: 142, figure 7.33e and f). Less common in tunics than the star and cross motifs, it sometimes is incorporated into the lower part of a panel separated from the rest of the tunic through the use of a discontinuous warp (Figure 5). ${ }^{7}$ In a fragment in the collections of the PMH (46-77-30/7386), however, this motif features above the k'uthu bars in the main panel.

An elaborate double-headed serpent may accompany the four-armed rhombus motif. One of the OGA tunics is particularly rich in motifs and includes more than one variant of a double-headed serpent (Misugi 1985: 91, No 157). Some fragments in the collections of the TM also incorporate fourarmed rhombuses and double-headed serpents (Rowe 1977: 72-73 and 103, figures 83 and 122). ${ }^{8}$

The colours used in tunics include red, yellow ochre or tan, dark blue (which sometimes has a green cast) and white. There was a range of variation, however. OGA Tunic 155 and T-19744 in MNAAHP both display large areas of fawn vicuña-coloured plain weave ground combined with pattern stripes containing a simple iconographic repertory. In Figure 1, the iconography is also simple, but the ground is strong red in colour. OGA tunic number 157 (Misugi 1985: 91) and MNAAHP oooo141843 display a greater range of iconographic complexity combined, in the case of the former, on a red ground and, of the latter, on a broadly striped red and dark blue ground.

\section{Women's dresses}

The identification of women's wrap-around dresses presents a greater challenge than is the case with men's tunics. A large textile in MNAAHP (T-19534), now incomplete, might have been a woman's garment because it is made from three webs sewn together, the central panel narrower than the outer two (Dransart 2000: 136, 153, figure 11). Assembling a large cloth from two or three panels is characteristic of the main garment worn by Inka women (Rowe 1995/1996: 12-13; Acosta Luna and Plazas García 2011: 4).

In textile T-19534, pattern stripes in complementarywarp weave are repeated across much of the width of each web, with two plain weave stripes, in dark red and yellow ochre, running along the side selvedges. Some of the complementary-warp weave stripes are flanked by two narrow stripes of complementary-warp weave, consisting of right-angled triangles stacked on top of each other. The triangles, when paired together across the two stacks, form isosceles triangles composed of two different colours (PAHMA 4-8216, Figure 8). In some cases, triangles are reflected in mirror-image to form a rhombus consisting of four conjoined right-angled triangles (Figure 9). Another example using this configuration of right-angled triangles to create rhombuses occurs in the textile from the Necrópolis San Francisco near Corire (Szykulski and Cárdenas 1999: Fig. 9).

These triangles have a counterpart in narrow painted designs appearing on Inka pottery. Catherine J. Julien (1993: 194 and 195, figure 7.6) illustrated a large fragment of an aríbalo in Sillustani Museum, which she considered to be a local variant of Mode B Cuzco-Inka ware. Two narrow stripes containing the stacked triangles flank the vessel's main panel and the triangles, dark in colour, stand out against the light coloured right-angled triangles forming the ground.

Stacked triangles also occur on a sherd Marion Tschopik (1946: 33, figure 19c) assigned to an Inka-related ceramic style, which she termed Urcusuyu Polychrome, with one stack of three triangles painted white on black and a second stack of triangles painted red on white. These pottery designs are more simple than those of the textiles because, even in polychrome, the triangles are painted in a single colour without internal subdivisions. In the textiles, the two 


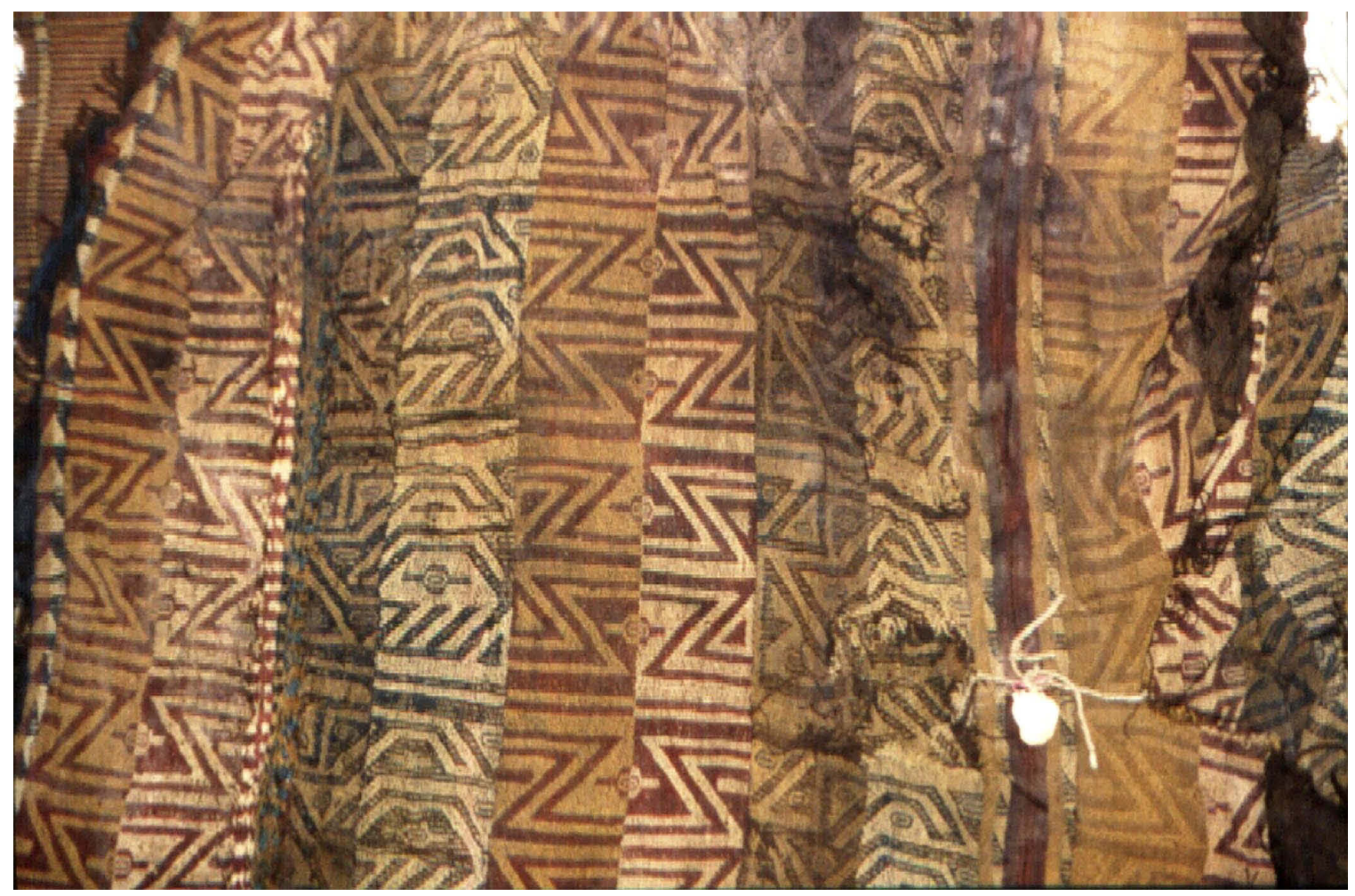

Figure 8. Fragment of a tentatively identified woman's dress from the highlands of the far south of Peru, depicting repeats of the 'butterfly' motif accompanied by a narrow stripe of paired right-angled triangles joined to form isosceles triangles. Phoebe A. Hearst Museum of Anthropology, 4-8216.
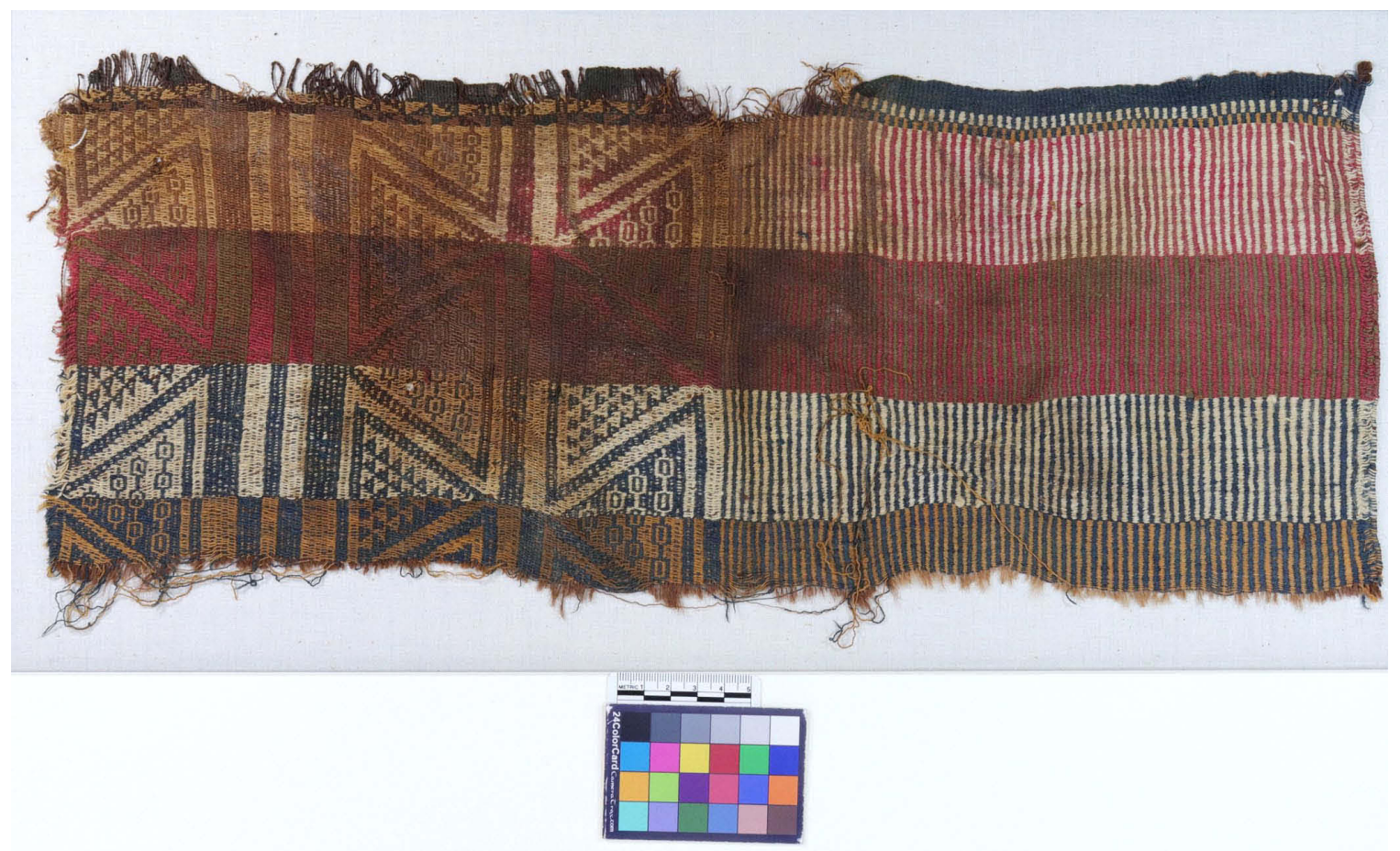

Figure 9. Fragment of a tentatively identified woman's dress, found by Max Uhle in tomb at Hacienda Lampilla, woven in warp-face plain weave and complementary-warp weave (with an uneven warp count). Note the narrow double stripe containing paired light- and darkcoloured right-angled triangles, reflected to make quadripartite rhombuses, close to the side selvedge at the top of the textile in this photograph. Phoebe A. Hearst Museum of Anthropology, 4-8217. 
different colours of right-angled triangle unite visually to form one isosceles triangle and may also be combined to form rhombuses. These narrow stripes seem to serve as a signature of highland identity under the spread of Inka dominance. They appear to be associated preferentially with women's dresses rather than men's tunics.

The broader pattern stripes in women's garments contain double-headed serpents similar to those occurring in men's tunics. Sometimes they are accompanied by another motif, which is only exceptionally present in the tunics. This second motif consists of two large isosceles triangles joined at the apex with a horizontal bar across the join. Both motifs appear on MNAAHP's T-19534 and the second motif features on fragments 4-8216 and 4-8217 in the Phoebe A. Hearst Museum of Anthropology (Figures 8 and 9). Because the design is bisected vertically by a colour change, one might be tempted to 'read' the design as a repeating series of ' $\mathrm{Z}$ ' shapes. In the card index files of PAHMA, textile 4-8216 was described as 'Fragment with white, yellow, blue, and red stripes containing "Z" design'. The design is possibly an extremely abstract rendition of a butterfly. ${ }^{9}$

Guaman Poma's early seventeenth-century drawing of the ninth Inka quya, or queen, shows Mama Ana Uarque wearing a shawl and a dress decorated with butterfly motifs (Figure 10). In his verbal description of the quya's garments, he wrote: 'y tenia su lliclla de rrosado y lo del medio blanco y su acxo de uerde y lo de auajo billpi[n]to y su chunbe de colorado' (Guaman Poma 1615: 137). ${ }^{10}$ His illustration seems to refer to the ninth quya's claim over the Collao by including a visual image associated with women's dress as worn in Titicaca Lakeside communities. Endemic butterfly species found in the south of Peru include the Neotropical polyommatine lycaenids with a pattern of dark spots under the wings. Examples are the Madeleinea colca, with spots on the underside of its fore and hind wings, and Nabokovia cuzquenha, with spots on the underside of the hind wings (Bálint and Lamas 1996: 130-131, figures 1-12). These butterflies feed on nectar in high altitude pasturelands. They are small and provide instances of possible sources of visual inspiration.

A characteristic feature of many of the woven butterflies is the horizontal bar at the point where the apex of one triangle meets the other to form the body. The weaver interchanged the warp threads in the complementary-warp weave to produce the butterfly's body as a simple bar (see Rowe 1977: 67). The wings of the butterfly display 'eyes' or spots, which are absent when painted on pottery.

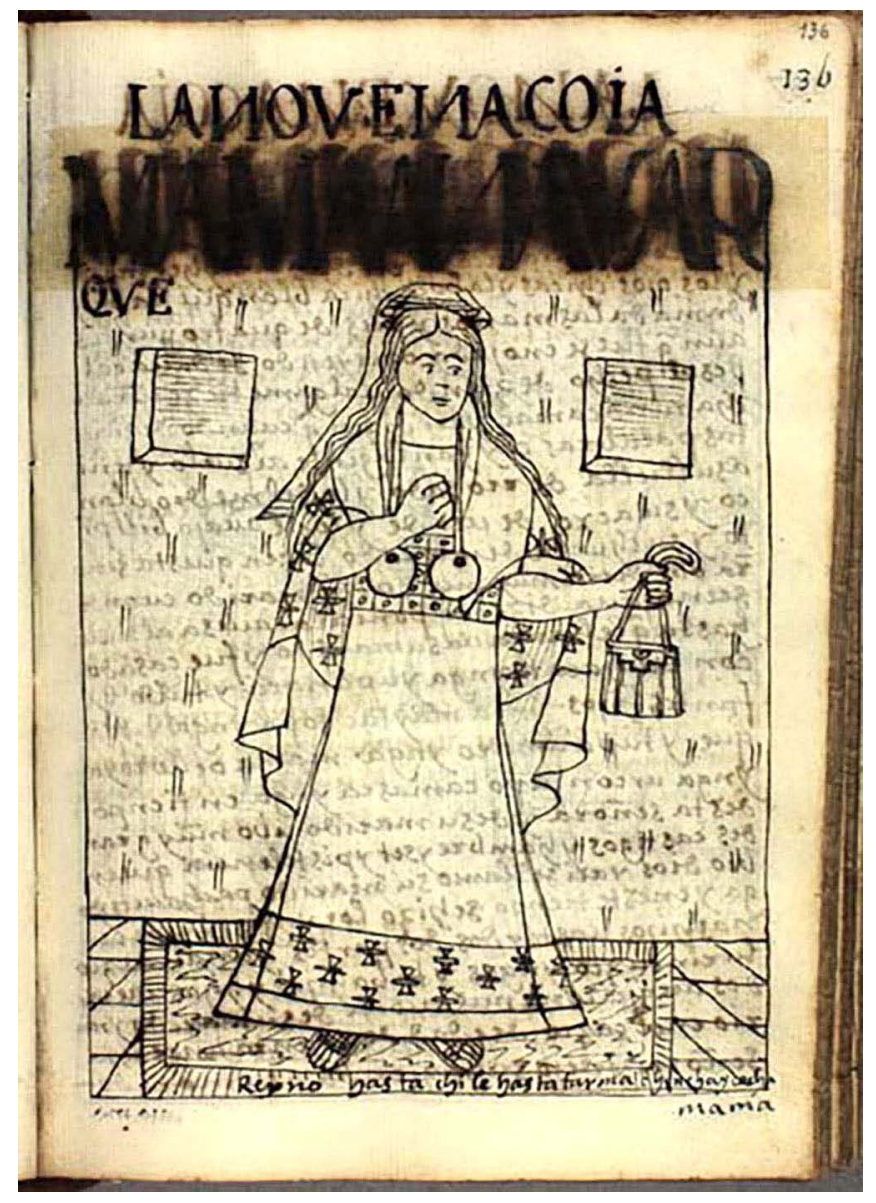

Figure 1o. The ninth Quya [queen] Mama Ana Uarque, with pillpintu ('small butterfly') motifs on her dress and mantle. By courtesy of Royal Danish Library, GKS $22324^{\circ}$ : Guaman Poma, Nueva corónica y buen gobierno (c. 1615), page 136.

In some textiles, the butterfly motif is further compressed with the omission of this horizontal bar. MNAAHP oooo252850 and TM 91.379 are both fragments in which a row of butterfly motifs is presented as paired isosceles triangles, joined at the point, with other triangles filling the negative spaces between the motifs. ${ }^{11}$ The body of the butterfly has disappeared, but the triangular wings are filled with up to fourteen 'eyes' or spots.

This compressed motif joined at the apex features in late pre-Inka pottery styles associated with the Collao. In reported examples, it is painted on the neck of Collao Black on Red jars (Tschopik 1946: 24, figures 9a, b, c, d and g; Arkush 2012: 312, Fig. 17) and on the body of Allita Amaya Polychrome jars, from a burial immediately south-east of Chucuito (Tschopik

9. I wish to thank Elena Phipps for commenting on the resemblance to a butterfly.

10. 'and her lliklla [shawl] of pink, and white in the middle, and her acxo [dress] of green with pillpintu [butterfly] below and her belt [chumpi] of red'. In the dictionary of Gonçalez Holguin (1608: 283), pillpintu is translated as 'mariposa pequeña' [small butterfly].

11. The fragment in the TM is illustrated in Rowe (1977: 72, figure 83). 
1946: 34, figures 20a, b and d). Collao Black on Red pottery is mostly encountered immediately north-west of Lake Titicaca, where it corresponds approximately to the area occupied by the Qolla people, with some indication that the distribution extends towards the south-east of the Lake (Carlevato 1988: $41,45)$. On the Collao and Allita Amaya vessels, the designs are cursive in appearance. Sometimes the butterfly motif has a solid infill or, alternatively, the interior space is crossed or hatched by a series of painted lines. The motif also is found neatly painted on the inside of an incomplete Taraco Polychrome bowl from Chucuito, a finely tempered ware with a white or cream-coloured paste (Tschopik 1946: 31-32, figure 18e). When the motif occurs in Inka aríbalos, it is painted in a controlled manner. ${ }^{12}$ The motif was known in communities surrounding Lake Titicaca before and during the period of Inka dominance. Dresses worn locally by at least some women in the highlands of the far south of Peru were therefore decorated with a motif associated with the Collao (the butterfly), flanked by a recognizably Inka design (the stacked triangles).

Long stretches of k'uthu are characteristic of the mostly fragmentary textiles cautiously identified here as having come from women's garments, which may be parts of the main dress or of the shawl that women surely used to cover the shoulders and arms. Unlike the men's tunics, however, these garments would have been worn with the warp oriented horizontally rather than vertically and the k'uthu bars would have appeared as vertical elements in the design.

\section{Belts, Bands and Pins}

Women's dresses were wrapped round the wearer's body, held in place at the waist by a belt and fastened with a long pin, one on each shoulder. Ludovico Bertonio (1612, I: 240, II: 185) stated that these pins were made from cactus spines or copper. Other materials are known from archaeological excavations. Two bronze dress pins were excavated from a burial of human remains inside a reused Inka urn at Cutimbo, near Puno, in Lupaqa territory (Tantaleán 2006: 137). Dress pins have also been reported from burials spanning the very end of the Late Horizon and early Colonial Period at an Inka-style building that was converted into a Christian church at Churajón, near Arequipa. These pins were made from cactus spine, bronze and silver (Szykulski 1998: 310-313).

Convincing examples of belts have yet to be identified in museum collections. The American Museum of Natural History has some narrow bands woven patterned with one or two narrow warp-faced stripes running along the length of the band. The narrow stripes split and diverge to form transposed-warp rhombuses. Catalogue number 41.0/3509 is $30 \mathrm{~mm}$ wide and, like the narrow k'uthu stripes and rhombuses on some of the men's tunics, the pattern stripe is woven in red and white yarns. This band is therefore related to the design of men's tunics.

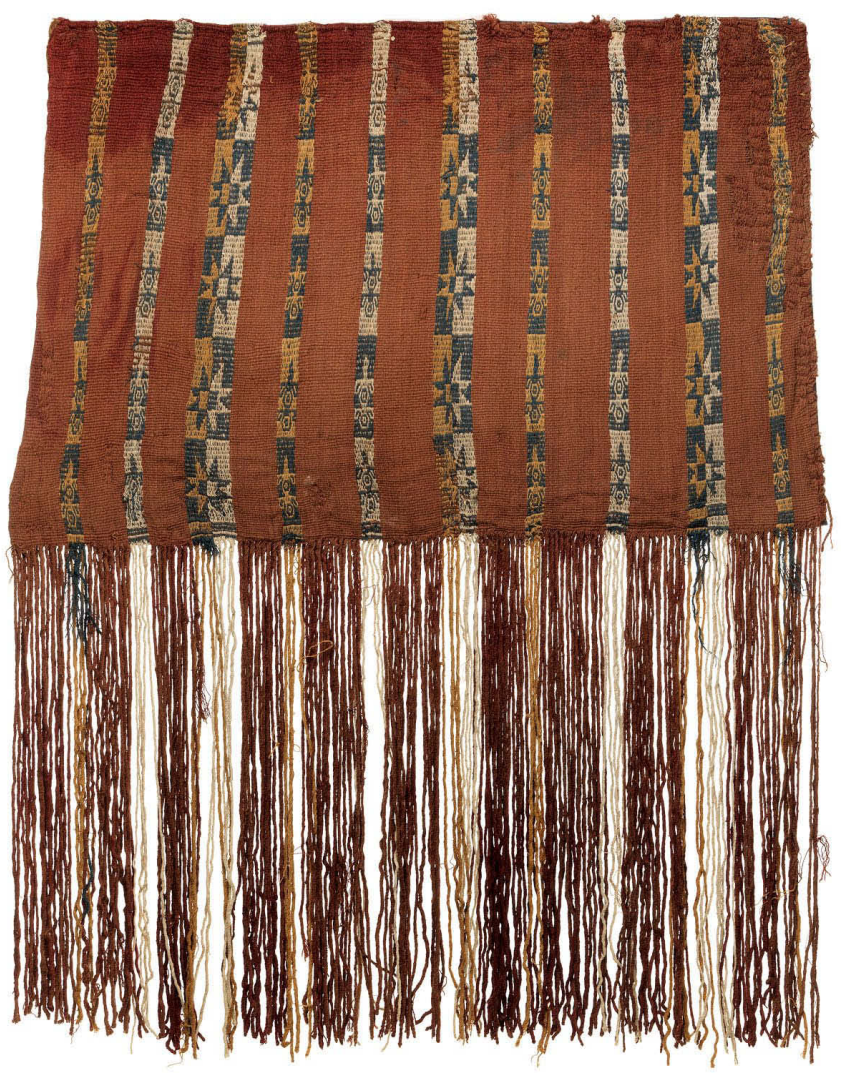

Figure 11. One side of a bag from the highlands of the far south of Peru, woven in warp-faced plain weave and complementary-warp weave (with an uneven warp count). Museum aan de Stroom, Antwerp, donated by Pollet Liban, AE.1999.0910.

\section{Bags}

Figures 11 and 12 show a bag in the collections of the Museum an der Stroom, Antwerp (AE.1999.0910), of which one side has survived. It is impressively large in size, measuring $400 \mathrm{~mm}$ deep (without the fringe), with a maximum width of $645 \mathrm{~mm}$. The patterning of the bag resembles that found in men's tunics. Plain red warp-faced weave stripes, now faded, are separated by wide complementary-warp woven stripes containing eight-pointed stars, the centre of which is the same as the ground, and narrow stripes containing stylized

12. See, for example, Matos (1999: 140) for an example of a Cuzco-Inca Mode A aríbalo in the Museo Inka del Cuzco, and catalogue numbers ooooo79577 and ooooo67122 in the MNAAHP. 


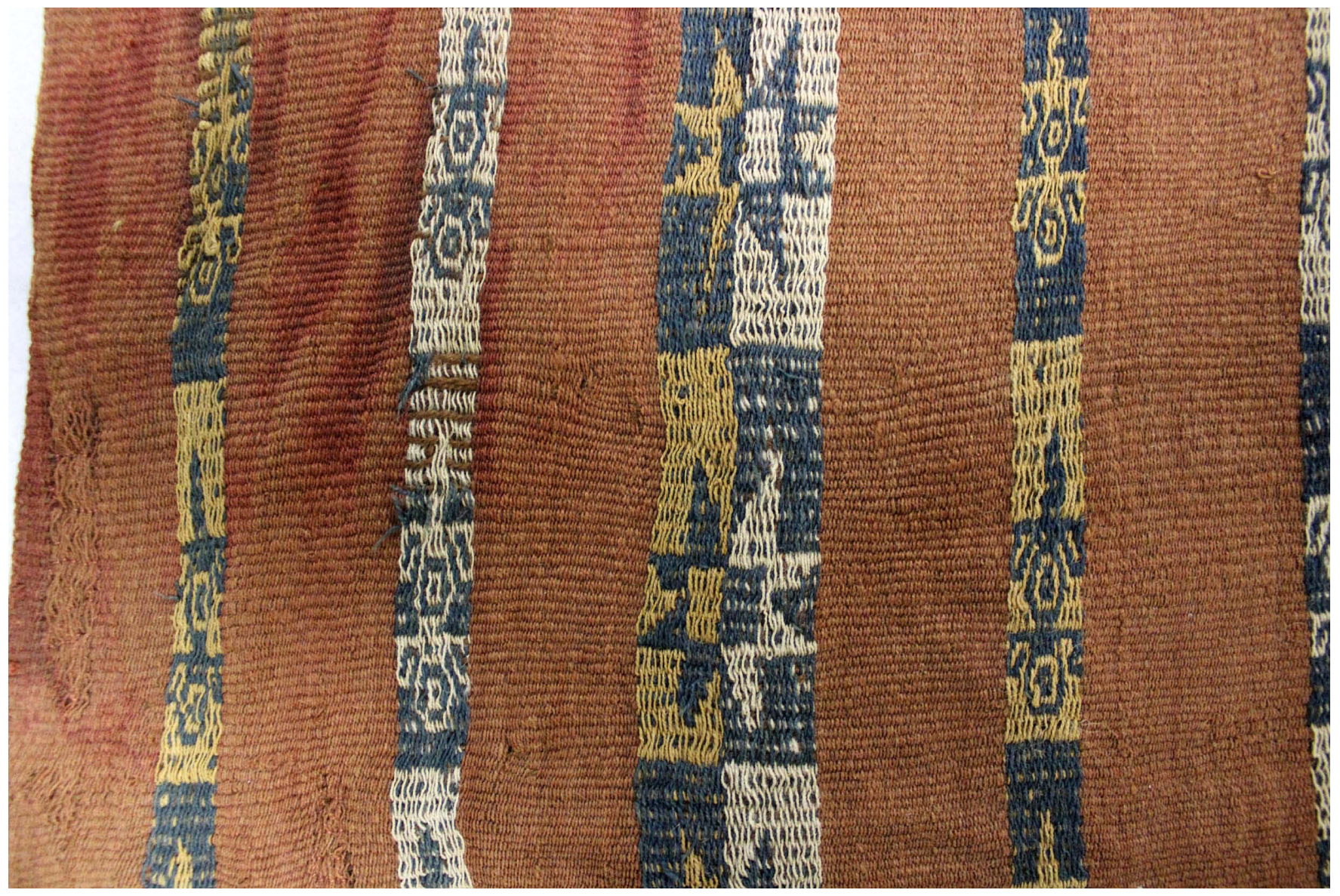

Figure 12. Detail of Figure 11, showing the faded red of the plain warp-faced stripes and the pattern stripes of complementary-warp weave (with an uneven warp count). The undyed brown weft is visible in the worn area of the second pattern stripe from the left. Extra weft threads can be seen crossing the third pattern stripe, inserted by the weaver to keep the weft at right angles to the warp. Photograph: Penelope Dransart.

lizard motifs. The wide pattern stripes are divided longitudinally with the design executed in dark blue and yellow ochre on one side of the stripe and dark blue and white on the other. Comparable in size, but rather more trapezoidal in shape, is a bag in the MA (inventory number 02-5-207, catalogue number 342 in Jiménez Díaz 2004: 373). It has a series of eleven narrow pattern stripes with similar lizard-like motifs, as in the Antwerp bag. The colour scheme is also closely comparable, with alternating colours of white and dark blue and tan and dark blue, although the plain red ground is of a much stronger hue. Because the MA bag is in a pristine condition, María Jesús Jiménez Díaz (2004: 373) suggested it might have been woven for a funerary or other ritual context. ${ }^{13}$ The size of such bags would make them suitable for containing sufficient coca leaves (or other items) for use in collective rites involving large numbers of participants.
A worn bag in the collections of Bryn Mawr College (2000.3.124.c) also has a red ground. It is patterned with two sets of paired stripes, in complementary-warp weave, containing eight pointed stars. Three narrow red and white stripes bearing transposed-warp rhombuses separate the two pairs of stripes.

These three bags are associated with the motifs used in men's tunics. A fringed bag in the Peabody Museum, Harvard, item 46-81-30/5533, is made from what looks like a piece taken from a women's dress. It has four broad stripes woven in complementary-warp weave in the following colour sequence: red and tan, dark blue and tan, dark blue and white, and red and tan. On one side of the bag, there is a double narrow stripe containing stacked isosceles triangles. With a width of about $440 \mathrm{~mm}$, this bag, too, is of a substantial size. 
To summarise the principal features in the textile tradition presented thus far, men's tunics were constructed from narrow panels and women's dresses are tentatively identified as consisting of a large wrap-around cloth made from three loom lengths sewn together. These textiles have patterning in the warp, which is oriented vertically in the tunics as worn and horizontally in the dresses. In both tunics and dresses, the pattern stripes in complementary-warp weave have long areas of k'uthu or peinecillo bars. Some tunics are articulated internally through the use of a discontinuous warp, forming lower panels reaching to the knee of the wearer. Tunics and belts/bands may also be patterned with narrow stripes of red and white k'uthu bars, in which the warp is transposed to form rhombuses. Motifs on tunics and bags often include eight-pointed stars, in which case the centre of the star is the same colour as the ground (unlike Chuquibamba stars). Double-headed serpents occur in the pattern stripes on both dresses and tunics. Dresses (and shawls?) may also be patterned in a stylized motif tentatively identified as a butterfly. A characteristic double narrow stripe containing right-angled triangles, which conjoin to form stacked isosceles triangles and rhombuses, tends to be associated with dresses and is associated with Inka pottery designs.

Warp and weft in all these garments are of camelid fibre. The colour palette usually consists of crimson red, dark blue (or dark green-blue), yellow ochre and/or tan and white in the warp, while the weft is undyed brown. Yellow ochre and tan play a more prominent role than in the earlier Chiribaya textiles, in which red and dark colours from purple to black predominate (Minkes 2005: 140). Green and yellow are much brighter in Chuquibamba textiles, but Chloé Tessier-Brusetti (2016: 101) suggests that during the period when Chuquibamba fell under Inka control, the colours became more 'terrosos' ('earthy').

\section{Locating the Producer Communities of the Textile Tradition}

In this section I turn to interpretations of archaeological and documentary evidence in the far south of Peru in order to contextualise the textile tradition defined in this article. This tradition made use of practices such as transposed warpweave, characteristically used in the South-Central Andes rather than the Central Andes (Figure 3). The alternation between light on dark and dark on light in positive-negative colour changes is also typical of the South-Central Andes (Minkes 2005: 141; Horta 1997: 88), as is cross-knit loop stitching in alternating blocks of light red and greenish-blue yarns at the arm and neck openings of the tunic in the MA (14676). This colour sequencing, combined with perpendicular stitching at the base of the neck slot, is a feature used to reinforce tunic openings in the South-Central Andes (Jiménez Díaz 2004: 396). It probably derives from Tiwanaku practices.

As two large, cultural-cum geographic units, the Central Andes and the South-Central Andes were defined by archaeologists on the basis of patterning observed in the material remains of pre-Hispanic societies. The division ran westwards from the Nudo de Vilcanota in Peru to the coast between the Sihuas and Tambo rivers (Lumbreras 1981; Lynch 1983: 1) (Figure 3).

The area Cieza de León (2005[1553]) called the Collao, in the South-Central Andes, consisted of a series of lakeside communities called Qolla, Lupaqa and Pacajes. ${ }^{14}$ They extended from Lake Titicaca's northern extent at Ayaviri, now in Peru, to as far south as Caracollo or Sicasica, now in Bolivia. Cieza de León referred to these communities as señoríos (lordships). Modern commentators understand them to have acquired political integration, but they de-emphasise the lordly role of an individual leader. Martti Pärssinen (1992: 261) regards the area as having the character of a Hatun apocazgo, or an 'interprovincial formation,' while Axel Nielsen (2008: 103-105) suggests these societies had a 'corporate mode of political action' and were led by 'hierarchies of groups rather than individuals.'

During the period of Inka domination, these communities gained considerably in political authority, exercising control over enclaves in the coastal valleys, where they settled their own people to engage in economic activities, including the cultivation of crops that could not be grown in the highlands. Prior to Inka expansion, the principal Lupaqa seat was perhaps at Cutimbo, south-west of Puno (Tantaleán 2006: 131). Based on the 'archipelago model of vertical control in the Andes' devised by John V. Murra (2002a, 2002b), the historian Carlos Sempat Assadourian (1995) characterized Lupaqa economic life during the early Colonial Period as combining a 'vertical archipelago,' of highland settlers established in discontinuous agricultural communities in the western valleys with 'horizontal trade' in the highlands. ${ }^{15}$

14. Alternative spellings used by different authors include Colla, Lupaka or Lupaca, Pacaxe.

15. To devise his model, Murra used evidence from Colonial Period documentation (especially Diez de San Miguel 1964[1567]) and ethnographically recorded accounts of contemporary communities in Peru and Bolivia. 
Whereas Murra argued that pre-Hispanic economic relationships were based on reciprocal exchanges between archipelagos and their parent communities in the highlands, Assadourian (1995) allowed for interethnic trading relations between the different highland communities. If such exchange relations existed in pre-Hispanic times, they would have facilitated the transmission of textile knowledge. Textile motifs in Late Horizon ceramics would have been shared 'horizontally' between interethnic contacts in the highlands and 'vertically' between parent and offspring communities established in the coastal valleys (Dransart 2014: 229).

Murra (2002a: 127) proposed that 'verticality' was a longstanding economic practice in the Andes and that Lupaqa enclaves at Sama, Moquegua and in the Azapa valley must have existed before the Inkas dominated the area. Archaeologists have explored Sama, in the middle reaches of the valley of the same name, and Torata Alta, in its eponymous valley, which drains into the Osmore River, for evidence of such enclaves (Trimborn 1977; Van Buren, Bürgi and Rice 1993). Torata Alta, however, appears to be a Lupaqa settlement made under the aegis of Inka domination because Van Buren (1996: 343) and Rice (2012: 9) demonstrate that it was intrusive, dating no earlier than about 1450/1475. It came under Spanish control after about 1535. Examples of possible Lupaqa settlements in the Azapa and Camarones Valleys have not been recognised. A bioarchaeological study of human remains suggests that genetic changes in populations living in these Chilean valleys are more like to have been the result of in situ microevolution rather than colonization by incoming people from the highlands (Sutter 2000: 63-64).

Hence the archaeological evidence does not support Murra's contention that there was a continuous process of highland settlement in the coastal valleys before the arrival of the Inkas. This important factor provides contextual assistance for identifying the textiles considered here because the chronological markers discussed above indicate that the textiles belong to the Late Horizon, as various authors have recognized (Rowe 1992: 33; Jiménez Díaz 2004: 396-397; Dransart 2014: 226).

The hillfort township of Pucarani, situated in Qolla territory north-west of Lake Titicaca, is an example of a large, nucleated settlement defended by monumentally constructed walling. It was characterised by a collective social organization without strongly marked internal hierarchy (Arkush and Ikehara 2019: 79). Study of its ceramics reveals various pottery types found in different sectors of the site, suggesting there were 'different practices of stylistic affiliation and ceramic use' among the inhabitants (Arkush and Ikehara 2019: 78-79). As is the case with the textiles, the ceramics do not convey a sense of ethnic exclusivity.
Shortly before Inka expansion into the area, highland communities began to acquire a more centralized political character than previously had been the case. During the reign of monarchs Pachacuti Inka and Ana Uarque, the Inkas claimed to have gained control of land as far as Chile 'and all its cordillera' (Guaman Poma 1615: 108, 136). Inka supremacy was first established in the highlands. Archaeologists have demonstrated that finds of highland ceramics, domestic architecture and burial customs in the coastal valleys date from after the onset of Inka dominance, when highland peoples were increasingly able to establish multi-ethnic enclaves at lower altitudes (Covey 2000: 125). The archaeological evidence demonstrates, nevertheless, that 'imperial control over the coast was never complete' (Covey 2000: 128). A consistent presence of highland peoples in coastal valleys only became possible when they served as allies under Inka rule. Inka settlements such as the Tambo de Jaqui (Hacienda Lampilla) date from the 1470 s onwards (Menzel 1959: 128), when members of Titicaca communities became empowered to carry out duties beyond their traditional highland domain.

The textile tradition defined in this article incorporated techniques and iconographic motifs that had been circulating in earlier traditions in the South-Central Andes. In particular, 'butterflies' can be seen in Collao and other pottery types found on sites north-west Lake Titicaca and near Chucuito, west of the lake. The butterfly was adopted as an Inka motif painted on polychrome pottery and, as mentioned above, Guaman Poma (1615: 137) referred to it in relation to the garments worn by the queen to whom he attributed the Inka conquest of the Titicaca lordships.

The stacked triangle motif and the eight-pointed star perhaps became incorporated into the textile tradition after the highlands in the far south of Peru came into contact with the Inkas. As explained above, the eight-pointed star also featured in weft-faced Chuquibamba textiles. At present, how this motif entered these two distinct traditions is not clear; it is possible they borrowed from sources independently.

Tunics, dresses and bags in the textile tradition defined here have been found in piedmont and coastal sites, suggesting that the people who wore the garments were interred in burials under Inka authority from a period beginning 14501475 that lasted until c.1540. These individuals had access to Inka and non-Inka pottery types. Burials in El Cementerio near Nazca, Hacienda Lampilla, Yauca, the San Franciso necropolis in the Majes Valley, and at Santa Isabel de Siguas occur in places within the western Cuntisuyu region of the Inka empire, rather than in Qullasuyu, which included the highlands from where the textile tradition is most likely to have emanated. The textiles have not been reported from coastal valleys between the Tambo and Azapa valleys, an 
area that retained a strong linguistic identity into the Colonial Period under the name of Colesuyo (Cañeda Argüelles 1993: 29).

Detailed exploration of the significance of this distribution does not fall within the scope of the present article. Suffice it to say that when people from the highlands, now in the Departments of Puno and Arequipa, occupied places in the coastal valleys of Cuntisuyu, their main garments indicated a highland origin in a tradition with Tiwanaku antecedents. Under Inka protection, they established themselves in Cuntisuyu. Waning Chuquibamba influence was, perhaps, a factor. By the end of the fifteenth century, the period of magnificence in Chuquibamba textiles was becoming a distant memory.

\section{Concluding comments}

This article has proposed a definition for a highland tradition based on textiles largely lacking in provenance. A few cases have been recorded from known burial places on the coast and in piedmont valleys. I began with Cieza de León's comments that people's main garments in the Collao did not clearly signal their ethnic affiliation, although their headgear did. Evidently, Ludovico Bertonio (1612), the compiler of an Aymara-Spanish dictionary, had a similar reaction. Working in the headquarters of the Society of Jesus at Juli, in Lupaqa territory, some seven decades after the European invasion, he recognized differences between Lupaqa and Qolla women's headdress known as phant'a (Bertonio 1612, II: 256). His entries on people's main garments do not convey information on ethnic dissimilarities.

On the other hand, Bertonio paid a great deal of attention to distinctions between women and men's attire. These entries are valuable for helping to demonstrate how garments of the tradition described above were worn. He listed the complete dress of a woman as 'manto y saya de muger, faxa', while that of a man included 'manta y camiseta' (Bertonio 1612, II: 304). ${ }^{16}$ This list mentions only the outwardly visible garments rather than items such as loin cloths. ${ }^{17}$ Women's dress had one opening, called pheque (p'iqi in modern Aymara spelling; see Arnold, Yapita and Aguilar 2014: 71). It was for both the arms and the head because the top of the fabric was folded over and pinned at the shoulders after the wearer wrapped the cloth round her body and wound a belt (or belts) firmly round the waist. She could then carry items placed in the bosom of the dress (Bertonio II: 263). In highland communities in the far south of Peru, women carried a baby inside the garment, as if in a pouch next to the naked skin. This customary practice met with disfavour during the Colonial Period and, on 6 November 1575, the Viceroy Francisco de Toledo (1929[1575]: 371) issued an edict in Arequipa forbidding women from doing so.

Men, in contrast, pulled the camiseta over the head through a neck opening called ccautata (q'awtata) and through an opening for each arm, called locusu (luqusu, from the Aymara luqu, an arm, Bertonio 1612, I:3, II: 41, 196). As mentioned above, stitching characteristic of the South-Central Andes reinforced the openings of tunic MA 14676 (Jiménez Díaz 2004: 396)

The textiles were woven and worn during a period when Inka goods in the region were gaining increased recognisability. Bird-headed plates and large aríbalo vessels were now circulating through the far south of Peru, whether in the form of Cuzco wares or of provincially produced versions (Covey 2000: 134). An Inka marker, a double narrow stripe containing stacked triangles, became a feature of the textiles. Other features derive from ancient traditions associated with the South-Central Andes employing warp-faced weaving, transposed warp rhombuses and colour alternations. This article has reported work in progress into the definition of a textile tradition. It is hoped that by sharing the results of this research, highland peoples of the far south of Peru and their interactions with peoples in the coastal valleys can be glimpsed with a little more clarity than has been the case up to the present.

\section{Acknowledgements}

A number of people have made this research possible and I wish to express my deepest gratitude to Sophie Desrosiers, Mary Frame, Ylva Frögéli, Mireille Holsbeke, Caitlyn Kennedy, Tessa Lummis, Elena Phipps and Ann Pollard Rowe. I thank Ann H. Peters and Lena Bjerregaard for their considerable help over editorial matters.

\section{Museum collections and abbreviations}

List of museums mentioned and abbreviations (where used in the text). URLs are provided for the online catalogues maintained by most (but not all) of these museums; these are correct as of 31 October 2019.

American Museum of Natural History, New York https://www.amnh.org/research/anthropology/collections British Museum, London (BM)

https://www.britishmuseum.org/research/collection online/search.aspx

16. Women's dress consisted of 'mantle and woman's garment, belt' and men's of 'shawl and tunic' (Bertonio 1612, II: 304). 17. Elsewhere in the dictionary Bertonio (1612 I: 345) listed 'Pañetes o bragas: Vecara [wiqara]' for undergarments. 
Bryn Mawr College Art and Artifact Collections

http://www.brynmawr.edu/collections/

Metropolitan Museum of Art, New York https://www.metmuseum.org/art/collection

Museo de América, Madrid (MA) http://www.culturaydeporte.gob.es/museodeamerica/ coleccion/acceso-a-catalogo2.html

Museo Nacional de Arqueología, Arte e Historia del Perú, Lima (MNAAHP)

http://mnaahp.cultura.pe/catalogo-en-linea

Museum aan de Stroom, Antwerp (MAS) https://search.mas.be/search/simple

Ohara Gallery of Art (OGA)

Peabody Museum of Archaeology and Ethnology at Harvard University (PMH) https://pmem.unix.fas.harvard.edu:8443/peabody/

Phoebe A. Hearst Museum of Anthropology, Berkeley, California (PAHMA) https://portal.hearstmuseum.berkeley.edu

Varldskultur Museerna: Etnografiska, Stockholm http://www.kringla.nu/kringla/

Textile Museum, George Washington University (TM)

\section{References cited}

Acosta Luna, Olga Isabel and Plazas García, María Catalina 2011. El manto o acso de la reina mujer de Atahualpa. ¿Una prenda de la última reina del Perú? Museo Nacional de Colombia, Cuadernos de Curaduría 12.

Arkush, Elizabeth 2012. Los pukara y el poder: los collas en la cuenca septentrional del Titicaca. In Arqueología de la cuenca del Titicaca, Perú. Edited by Luis Flores Blanco and Henry Tantaleán, 295-319. Lima: IFEA and Cotsen Institute of Archaeology.

Arkush, Elizabeth and Ikehara, Hugo C. 2019. Pucarani: Defensive Monumentality and Political Leadership in the Late Pre-Columbian Andes, Journal of Anthropological Archaeology 53: 66-81.

Arnold, Denise Y., and Espejo, Elvira 2012. Ciencia del tejer en los Andes: estructuras y técnicas de faz de urdimbre. La Paz: Fundación del Banco Central de Bolivia, Fundación Interamericana, Fundación Albó e ILCA.

- 2015. The Andean Science of Weaving: Structures and Techniques of Warp-Faced Weaves. New York: Thames \& Hudson.

Arnold, Denise Y, and Yapita, Juan de Dios, with Aguilar, María Juana 2014. Los términos textiles aymaras del siglo XVII de la región lacustre, en base al Vocabulario de la lengua Aymara por Ludovico Bertonio: Vocabulario semántico según la cadena productiva. La Paz: ILCA: Serie Informes de Investigación, II, No 10.

Assadourian, Carlos Sempat 1995. Exchange in the ethnic territories between 1530 and 1567: The Visitas of
Huánuco and Chucuito. In Ethnicity, Markets, and Migration in the Andes: At the Crossroads of History and Anthropology. Edited by Brooke Larson, Olivia Harris, and Enrique Tandeter, 101-134. Durham, NC: Duke University Press.

Bálint, Zs. and Lamas, G. 1996. On the Taxonomy of the Neoptropical Polyommatine Lycaenids (Lepidotera: Lycaenidae, Polyommatini), Annales Historico-Naturales Musei Nationalis Hungarici 88: 127-144.

Bertonio, Ludovico 1612. Vocabulario de la lengua aymara. Juli, Province of Chucuito: Printed in the house of the Society of Jesus by Francisco del Canto.

Boytner, Ran 1998. Textiles from the Lower Osmore Valley, Southern Peru: A Cultural Interpretation, Andean Past 5: 325-356.

Carlevato, Denise 1988. Late Ceramics from Pucara, Puno: An Indicator of Changing Site Function, Expedition 30(3): 39-45.

Cañeda Argüelles, Teresa 1993. La organización del poder indigena en el Colesuyo (siglo XVI). Revista Complutense de Historia de América 19: 21-51.

Cieza de León, Pedro de 2005 [1553]. Crónica del Perú. El señorío de los Incas. Selección, prólogo, modernización del texto, cronología y bibliografía by Franklin Pease G.Y. Caracas: Biblioteca Ayacucho.

Covey, R. Alan 200o. Inka Administration of the Far South Coast of Peru, Latin American Antiquity 11(2): 119-138.

Cuynet, François 2012. Las esculturas Pukara: sintésis del conocimiento y verificación de los rasgos característicos. In Arqueología de la Cuenca del Titicaca, Perú. Edited by Luis Flores Blanco and Herny Tantaleán, 217-224. Lima: IFEA and Cotsen Institute of Archaeology.

De Toledo, Francisco 1929 [1575]. Ordenanzas de Don Francisco de Toledo Virrey del Perú 1569-1581, with a preface by Roberto Levillier. Madrid: Imprenta de Juan Pueyo.

Diez de San Miguel, Garci 1964 [1567] Visita hecha a la Provincia de Chucuito por Garci Diez de San Miguel en el ano 1567. Lima: Casa de la Cultura del Perú.

Dransart, Penelope 200o. Vestirse en los períodos tardíos del centro-sur peruano. In Actas de la I Jornada Internacional sobre Textiles Precolombinos. Edited by Victoria Solanilla Demestre, 127-153. Barcelona: Grup d'Estudis Precolombins.

2014. Thoughts on productive knowledge in Andean weaving with discontinuous warp and weft. In Textiles, Technical Practice and Power in the Andes. Edited by Denise Arnold with Penelope Dransart, 216-232. London: Thames and Hudson.

in press. Una estética del hacer. Miradas sobre las bolsas prehispánicas tardías de Doncellas (Puna septentrional argentina), Estudios Sociales del NOA - Nueva Serie 22. 
Espejo, Elvira and Arnold, Denise Y. (2014). Woven techniques and social interactions in the South Central Andes: ladder designs and the visualisation of productive output. In Textiles, technical practice, and power in the Andes, edited by Denise Y. Arnold with Penelope Dransart, 303-326. London: Archetype.

Frame, Mary 1997-1998. Chuquibamba: A Highland Textile Style, The Textile Museum Journal 36 and 37: 3-47.

Gonçalez Holguien, Diego 16o8. Vocabulario dela lengua general de todo el Peru llamada lengua Qquichua, o del Inca. Corregido y renovado conforme ala propriedad cortesana del Cuzco. Ciudad de los Reyes [Lima]: printed for Francisco del Canto.

Guaman Poma de Ayala, Felipe 1615. Nueva corónica y buen gobierno. Royal Danish Library, GKS $22324^{\circ}$ http://www. kb.dk/permalink/2006/poma/info/es/foreword.htm

Horta Tricallotis, Helena 1997 (published 1999). Estudio iconográfico de textiles arqueológicos del Valle de Azapa, Arica, Revista Chungara 29(1): 81-108.

- 2005. Arte textil prehispánico. Diseños de los tejidos de la cultura Arica, norte de Chile (10oo-1470 d.C.). Santiago: Editorial Universidad Bolivariano.

Jiménez Díaz, María Jesús 2004. Tejidos y mundo textil en los Andes Centrales y Centro-Sur a través de la colección del Museo de América de Madrid: Períodos Prehispánico y Colonial. Doctoral thesis presented to the Universidad Complutense de Madrid.

Julien, Catherine J. 1993. Finding a Fit: Archaeology and Ethnohistory of the Incas. In Provincial Inca: Archaeological and ethnohistorical assessment of the impact of the Inca State, edited by Michael A. Malpass, 177-233. Iowa City: University of Iowa Press.

Kroeber, Alfred L. 1944. Peruvian Archaeology in 1942. Viking Fund Publications in Anthropology, No 4. New York.

Laurencich Minelli, Laura 200o. Los textiles peruanos del documento ‘Exsul Immeritus Blas Valera Populo Suo’: una propuesta de lectura. In Actas de la I Jornada sobre Textiles precolombinos, edited by Victòria Solanilla Demestre. Barcelona: Universitat Autònoma de Barcelona, Departament d'Art, 154-176.

- (ed) 2005. Exsul Immeritus Blas Valera Populo Suo e Historia et Rudimenta Linguae Piruanorum. Indios, gesuiti e spagnoli in due documenti segreti sul Perù del XVII secolo. Bologna: CLUEB (Cooperativa Libraria Universitaria Editrice Bologna).

Lumbreras, Luis G. 1974. The Peoples and Cultures of Ancient Peru, translated by Betty J. Meggers. Washington, D.C.: Smithsonian Institution Press.

1981. Arqueología de la América Latina. Lima: Milla Batres.

Lynch, Thomas F. 1983. Camelid Pastoralism and the Emergence of Tiwanaku Civilization in the South-Central Andes, World Archaeology 15(1): 1-14.
Menzel, Dorothy 1959. The Inca Occupation of the South Coast of Peru, Southwestern Journal of Anthropology 15(2): 125-142.

Minkes, Willy 2005. Wrap the Dead: The Funerary Textile Tradition from the Osmore Valley, South Peru, and Its Social-Political Implications. Archaeological Studies, Leiden University 11. Leiden, The Netherlands: Faculty of Archaeology, Leiden University.

Misugi, T. (ed.). 1985. The Collection of Ohara Gallery of Art: The Andes - Textiles and Ceramics. Kobe: Shikosha Publishing Co.

Murra, John V. 2002a [1977]. Los límites y las limitaciones del 'Archipiélago vertical' en los Andes. In El mundo andino. Población, medio ambiente y economía, John V. Murra, 126131. Lima: Instituto de Estudios Peruanos.

_ 2002b [1968]. Un reíno Aymara en 1567. In El mundo andino. Población, medio ambiente y economía, John V. Murra, 183-207. Lima: Instituto de Estudios Peruanos.

Nielsen, Axel 2008. Poor Chiefs: Corporate Dimensions of PreInca Society in the Southern Andes. In Against Typological Tyranny in Archaeology, edited by Cristóbal Gnecco, 99-120. New York: Springer.

Pärssinen, Martti. 1992. Tawantinsuyu. The Inca state and its political organization. Helsinki: Societatas Historica Finlandiae, Studia Historica 43.

Rice, Prudence M. 2012. Torata Alta: An Administrative Center and Spanish Colonial Reducción in Moquegua, Peru, Latin American Antiquity 23(1): 3-28.

Rosenzwig, Alfredo, and Artzi, Bat-ami 2011. A Chiribaya Textile Woven with Human Hair, Boletín del Museo Chileno de Arte Precolombino 16(1): 93-104.

Rowe, Ann P. 1977. Warp-patterned weaves of the Andes. Washington, D.C.: The Textile Museum.

- 1992. Provincial Inca Tunics of the South Coast of Peru, Textile Museum Journal 31: 5-52.

_ 1995-1996. Inca Weaving and Costume, Textile Museum Journal 34/35: 5-53.

Sutter, Richard C. 200o. Prehistoric Genetic and Culture Change: A Bioarchaeological Search for Pre-Inka Altiplano Colonies in the Coastal Valleys of Moquegua, Peru, and Azapa, Chile, Latin American Antiquity 11(1): 43-70.

Szykulski, Józef 1998. Churajón, nuevos datos sobre el período de transición en el sur del Perú. In 50 Años de estudios americanos en la Universidade de Bonn, edited by Sabine Dedenbach-Salazar-Sáenz, Carmen Arellano Hoffman, Eva König and Heiko Prümers, 291-320. Bonn: Bonner Amerikanistiche Studien 30 and Verlag Anton Saurwein.

2010. Prehistoria del Perú sur (costa extremo sur), Tambo. Boletín de Arqueología 2.

Szykulski, Józef and María del Carmen Cárdenas Sumida 1999. Prospección en la Necrópolis San Francisco, Provincia Castilla, sur del Perú, Slaskie Sprawodzdania Archeologiczne 45: 385-395. 
Tantaleán, Henry 2006. Regresar para construir: practicas funerarias e ideología(s) durante la ocupación inka en Cutimbo, Puno-Perú, Chungara Revista de Antropología Chilena 38(1): 129-143.

Tessier-Brusetti, Chloé 2016. Translaciones estilísticas de los textiles Chuquibamba: testimonios de la mutación de una sociedad (costa sur del Perú, Intermedio Tardío). In El Perú en su historia. Fracturas y persistencias, edited by Chatherine Poupeney Hart, Sebastián Ferrero and Juan C. Godenzzi, 93-113. Paris: Éditions Le Manuscrit.

Trimborn, Hermann 1977. Excavaciones en Sama (Depto. Tacna, Perú), Indiana 4: 171-175.

Tschopik, Marion 1946. Some Notes on the Archaeology of the Department of Puno, Peru. Papers of the Peabody Museum of American Archaeology and Ethnology 27(3). Cambridge, MA: Harvard University.
Ulloa, Liliana 1982a. Evolución de la industria textil prehispánica de la zona de Arica, Chungara Revista de Antropología Chilena 8: 97-108.

1982b. Estilos decorativos y formas textiles de poblaciones agromarítimas, extremo norte de Chile, Chungara Revista de Antropología Chilena 8: 109-136.

Umire, Adán y Miranda, Ana 2001. Chiribaya de Ilo. Un aporte a su diffusion. Arequipa: CONCYTEC.

Uribe Rodríguez, Mauricio 1999. La cerámica de Arica 40 años después de Dauelsberg, Chungara Revista de Antropología Chilena 31(2): 189-228.

Van Buren, Mary, Bürgi, Peter, and Rice, Prudence 1993. Torata Alta: A Late Highland Settlement in the Osmore Drainage. In Domestic Architecture, Ethnicity and Complementarity in the South-Central Andes, edited by Mark Aldenderfer, 136146. Iowa City: University of Iowa Press. 